\title{
A BRIEF TO THE PUBLIC HEARINGS ON PRINCE ALBERT NATIONAL PARK
}

\author{
by J. S. Rowe, University of Saskatchewan, Saskatoon
}

\section{INTRODUCTION}

The Provisional Master Plan for Prince Albert National Park is an excellent one within the self-imposed limits of the planners. It appears to be firmly based on the commendable purpose set out in the booklet "National Parks Policy", viz. "to preserve for all time areas which contained significant geographical, geological, biological or historic features as a national heritage for the benefit, education and enjoyment of the people of Canada".

A criticism is that the policies are not as dynamic as these times of environmental crisis demand. Necessarily preoccupied with preservation, the planners have not perhaps recognized the challenge that a National Park and Wilderness network poses to misguided land use and the conventional "progress - through - development" philosophy. The idea of National Parks as comparable to museums or art galleries is good as far as it goes but, more profoundly, the National Parks can exemplify the "man - working - with nature" theme, showing how the world ecosystems function and how man may fit harmoniously into them, rather than how they may be fitted to man's uses.

People today, especially the young, are seeking a new life pattern and this is largely a question of finding new social and ecological (environmental) relationships. "What", they are asking, "is a good environment, in the city, town and hinterland?" In handling enormous numbers of visitors, the parks are confronted with what are essentially urban population problems, while at the same time they must attempt to provide all visitors with a "nature experience" in a wilderness setting. Essentially, then, they are at grips with the central environmental questions of the day. In microcosm the Parks must solve the inter-related problems of population and carrying capacity, of pollution, growth and development, of land use and conservation. But, and this is uniquely important, they must solve them in such a way that the landscape is preserved in a natural state. In other words, in this particular context, man is to be controlled in the interests of maintaining other forms of life. The message is a new one: that humans and the humanized landscape are not allimportant. A note of humility is struck which could be the beginning of wisdom.

\section{COMMENTS ON THE \\ NATIONAL PARKS POLICY}

Park Master Plans are guided by the "National Parks Policy" as set out in the 1969 publication (Cat. No.: R62-6269). It is appropriate therefore to comment first on the "Policy" and then on the Prince Albert National Park Provisional Plan.

\subsection{Categories of National Areas}

The suggestion in the "Introduction" that there is a need for more than one class of national area is good. The National Parks will be subject to pressures for every conceivable use unless alternative areas are provided elsewhere. For example, until there are designated National Recreational Areas (as well as Provincial, Regional and Urban Recreation Areas) it will be difficult to resist giving up ever-larger parts of the National Parks to those mechanized and gregarious forms of recreation with which the preservation of nature co-exists uneasily if at all.

Close to the National Parks philosophy and purpose are Natural Areas, conceived as representative of the natural terrain. The scattered parks cannot possibly comprehend all the richness of the Canadian landscape; there needs to be a supplementary network of smaller ecological reserves 




Pine in boreal forest

Saskatchewan Government Photo

that will protect examples of regional landforms, soils, flora and fauna. Such reserves, like the parks, have cultural and historical significance. They can be educational and research facilities, increasing man's awareness of the environment while providing aesthetic cnjoyment.

The International Biological Program has sponsored an inventory of candidate Natural Areas in all regions of Canada over the last few years, and the results will be available in 1972 . There should be consideration, cooperatively between the federal and provincial governments, of possibilities for integrating the system of Natural - Areas with the Parks and other National Areas.

\subsection{Purpose of National Parks}

Concerning the policy statement of the purpose of National Parks, it is difficult to escape the biases and pre-uppositions of one's own time. A wiser future generation will perhaps argue that preserving the natural landscape is a good in itself, an ethical imperative that needs no justification by reference to human "use". To talk of National Parks as a "resource" that "is valuable to man only when he can utilize it" (Policy, p. 4) may be necessary to sell the idea today. However, in this approach there are dangers, particularly the implication that nothing matters but man, his needs and his favoured pursuits. The message is anti-ecological. It plays into the hands of those who will argue convincingly that if for example a majority of visitors want to fish, then fishing there will be. The argument against hunting is thereby weakened, and if hunting why not the removal of other resources?

The "benefit, education and enjoyment" of the people of Canada will best be served when the establishment and preservation of National Parks is 
seen as a far-sighted step toward a better environment, a reversal of the trend toward technologic simplification of the landscape, a preference for diversity and natural beauty, a change from the attitude that proclaims economic gain to be all that matters. In other words, the purpose of National Parks should be conceived in the context of the current ecological revolution. Nothing less will make them wholly relevant.

\subsection{Recommendations concerning Parks Policy}

\subsubsection{It is essential that the National} Parks be viewed within a Canadawide (and world-wide) framework. The goals of the parks are not isolated from national (and international) goals, neither are they isolated from provincial and regional goals. The philosophy of re-creation lands must be inclusive and the roles of different categories of parks and other land uses should be rationalized and integrated. For example, the Prince Albert National Park plan should relate it to provincial and regional parks, to surrounding forest land uses, to national needs for the preservation of large wilderness areas.

2.3.2 It is essential that the interpretation programs of the National Parks be expanded so that the public (both visitors and nonvisitors) will be exposed within the next few years to an understanding of the goals and potentialities of the National Parks. The current goals and methods of interpretation -- chiefly relying on nature hikes, evening talks and museum displays-while useful do not go nearly far enough.

2.3.3 It is essential that research on the Parks, in the context of national and regional land use, be intensified on an inter-disciplinary basis, to provide sound ecological information and creative ideas for future development. Such research should involve top professionals in the fields of architec- ture, landscape planning, urban planning, the social sciences and humanities, as well as in the natural sciences. The aim should be the creation of a system of ideal environments, guided by the preservation ethic.

2.3.4 In order to gain broader support for the National Parks program and to involve people at the local level, Advisory Committees should be established with personnel from outside the government services. An Advisory Committee at the national level could usefully assist in the formulation of general policies, while Guiding Committees with regional representation could contribute to the local park policies. At present the National and Historic Parks Branch is handicapped by insufficient rapport with the public.

\section{PRINCE ALBERT NATIONAL PARK PROVISIONAL MASTER PLAN}

The Master Plan for Prince Albert National Park is very good. It shows a sensitivity to the policies of preservation. The following comments should be interpreted therefore as further encouragement of policies with which I am in agreement, and the proposals as means of introducing even greater consistency to the Plan.

\subsection{The Need for more Parks}

The planning of a park must surely be affected by other recreation facilities and other land uses in the vicinity. The proximity of Prince Albert National Park to Montreal Lake, Bittern Lake, Emma and Christopher Lakes, Nesslin Lake, etc., influences and will influence what pressures for use there are or will be. It is unfortunate that there does not seem to be any coordination of recreational land use in the boreal forest, involving the senior and provincial governments.

Concerning land use, the cutting of pulp on limits that surround the park on three sides may result in an influx of wild animals and humans, as preferred habitat for both deteriorates 
around lakes and streams. If, as seems likely, the park becomes an island in a logged-over sea, the pressures on it may suddenly and drastically increase in the next decade. The area and its facilities will probably prove to be too small.

More parks are needed to meet future recreational needs. The Prince Albert National Park should be supplemented by other National Parks northward on the Precambrian Shield where surface rocks, forests, lakes and streams provide a different boreal terrain, suited to canoe tripping and camping. The Churchill River should be considered, as well as the south shore of Lake Athabasca.

\subsection{Zoning}

The zoning system whereby $76 \%$ of the park is to be maintained as Wilderness, $16.7 \%$ as Natural Environment ("wilderness threshold") and $3.6 \%$ as Special Areas is satisfactory.

As mentioned earlier, the zoning itself might well be a feature accented in the park interpretation program. Here in microcosm is a plan for a region, with an urban center and an intensive-use zone surrounded by the fresh air, water and forests of a wilderness environment. A framework is established for overall management of the land, through harmonious integration of uses between the zones.

The banning of vehicles (boats, snowmobiles, etc.) from Class I and II land is strongly supported. "Powerintensive recreation" should be confined to other types of recreation areas.

Sandy Lake ought to be designated as entirely in Class III. It is not feasible to split a lake into two categories (III and IV) as shown on the map, unless there is some natural constriction as at the First Narrows. The proposed Class IV bay at the southwest corner of Sandy Lake will have the effect of converting it all to Class IV.

$$
\text { Special Areas (Class I) should }
$$
always be buffered by Class II lands. There are several areas in the south and west of the park where this has not been done.
It is recommended that the boundaries of the park be extended to take in the potential Class I areas around Isavallee Lake and the southwest corner. Adequate area for buffer zones will be needed.

Trail 57 from the west boundary should be re-routed east of its junction with Moose Trail to avoid the wolfdenning area southwest of the First Narrows.

\subsection{Resource Conservation}

As stated in the plan, there is a need for greater understanding of the park ecosystem; the landforms, water bodies, plants and animals and their inter-relations.

Ecologists are agreed that there is a relationship between diversity of terrain and preservation of varied forms of life. In other words, a complex pattern of different vegetation types on a variety of landscapes (both land and water) will guarantee survival of many more forms of life than will a simple monoculture such as an extensive pine plantation or an agricultural crop. Furthermore, the encouragement of diversity is a means of hedging against an uncertain future whose catastrophes and needs are unknown. Finally, diversity is aesthetically pleasing, as is suggested by the meaning of its near antonym "monotony". Therefore the maintenance of landscape diversity should guide the balancing of the "evolutionary" and "era" conservation concepts (Master Plan, p. 16).

It follows that every area and zone needs a management plan, even if the plan is "no management". Where diversity in plant and animal communities is a goal, there may have to be manipulation that mimics natural catastrophes such as floods and the windthrow of trees. Prescribed burning to maintain grasslands will almost certainly be necessary.

\subsection{Interpretation}

The interpretation program is the most important function of National Parks. It should be organized at various levels, from the simplest for 
small children to the sophisticated for intelligent adults. In some National Parks - not, fortunately, Prince Albert - the current interpretation programs can only be described as bloody awful.

I believe it is a mistake to treat the parks only as museums. They are that, but they can be much more; viz. a means of introducing the public to the very fundamental environmental crises that face the world today, perhaps suggesting some solutions. The typical visitor has come from a city or town where the media have made him very aware of pollution, population problems, poor planning. What is the Park's meaning and importance to him? Is it only a relic of the past, offering a momentary escape from the real world, or does it present an ideal and viable alternative from which he can learn how better to shape an environment fit for living?

"To be effective, interpretation must be based on knowledge". There is a challenge here to get the kind of

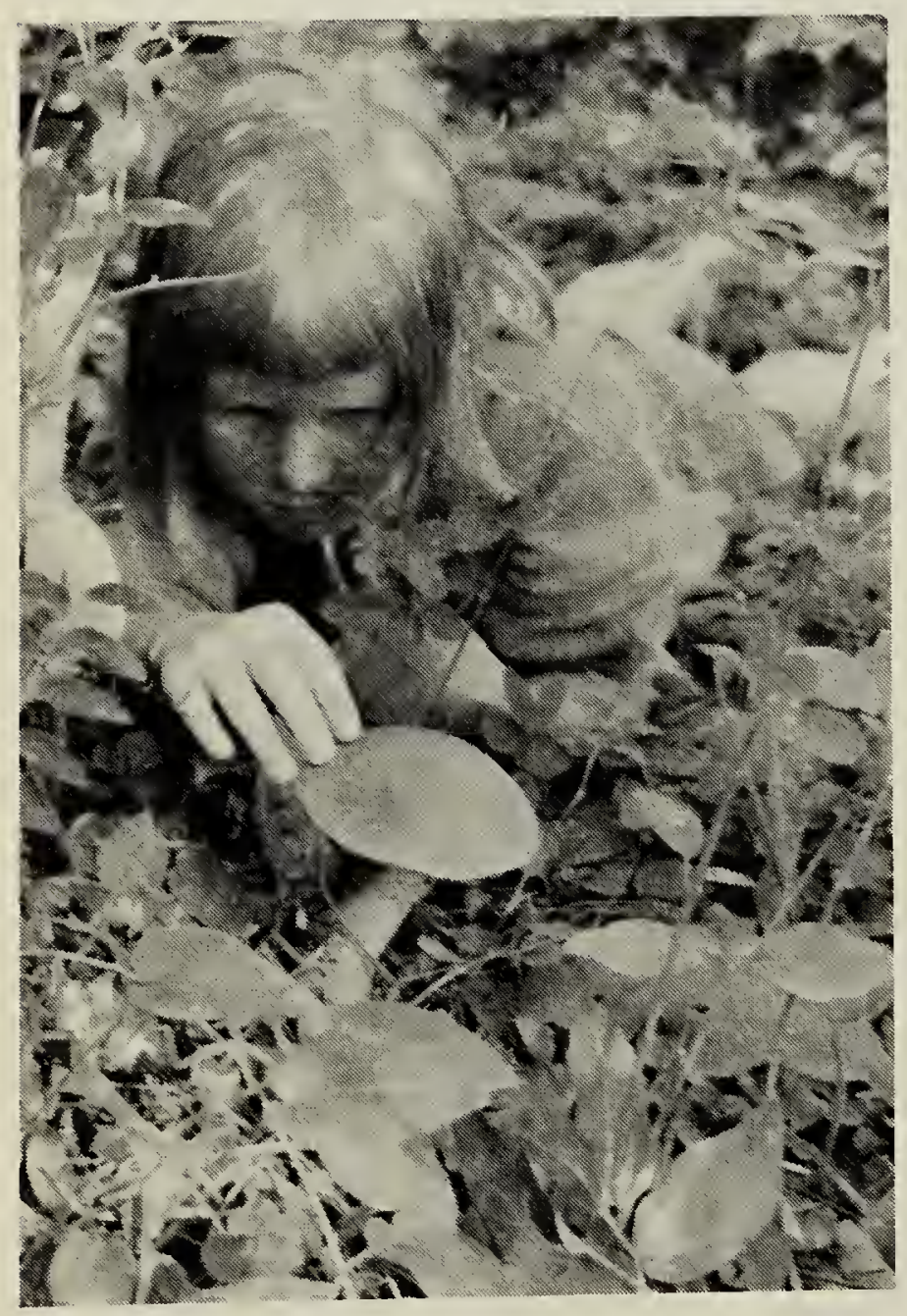

Discovering nature knowledge that will make the interpretation program creative in the widest sense. The National Film Board should be enlisted along with the necessary gifted people to produce professional audio-visual materials. Interpretive literature should be of higher quality. There should be more attention to methods of involving the visitors in activities that foster the learning process.

In the booklet "National Parks Policy" it is stated (page 10) that organized group camping is acceptable if it is oriented to the benefit, education and enjoyment of natural surroundings. The Parks should consider a program of education for public school children on a year-round basis, developing and maintaining facilities and providing leadership for students, say in Grade VIII, from throughout the province. This sort of facility is lacking in Saskatchewan though it has been provided by some large school districts in Ontario for many years.

\subsection{Development}

Roads should not invade Class I and Class II areas but, on the other hand, they should be built peripherally so that visitors can at least see some of "their wilderness". As suggested in the plan, there should be much more attention to road location, design and construction so that contact with the park landscape is emphasized. Some points of detail follow:

A vehicle ferry at the First Narrows will cause traffic pile up at that point; then a bridge will be demanded and the Narrows will lose its charm. It would be better to leave the roads unconnected across the Narrows as they are now.

The proposed loop drive west from Sandy Lake should be shortened, to run south from Hunters Lake, thus keeping it farther from and protecting the Potential Class I area in the southwest corner.

Hiking and bicycle trails should be established or extended as outlined on page 20. All trails and canoe routes need clear posting.

It is difficult to see the logic of encouraging horseback riding in the 


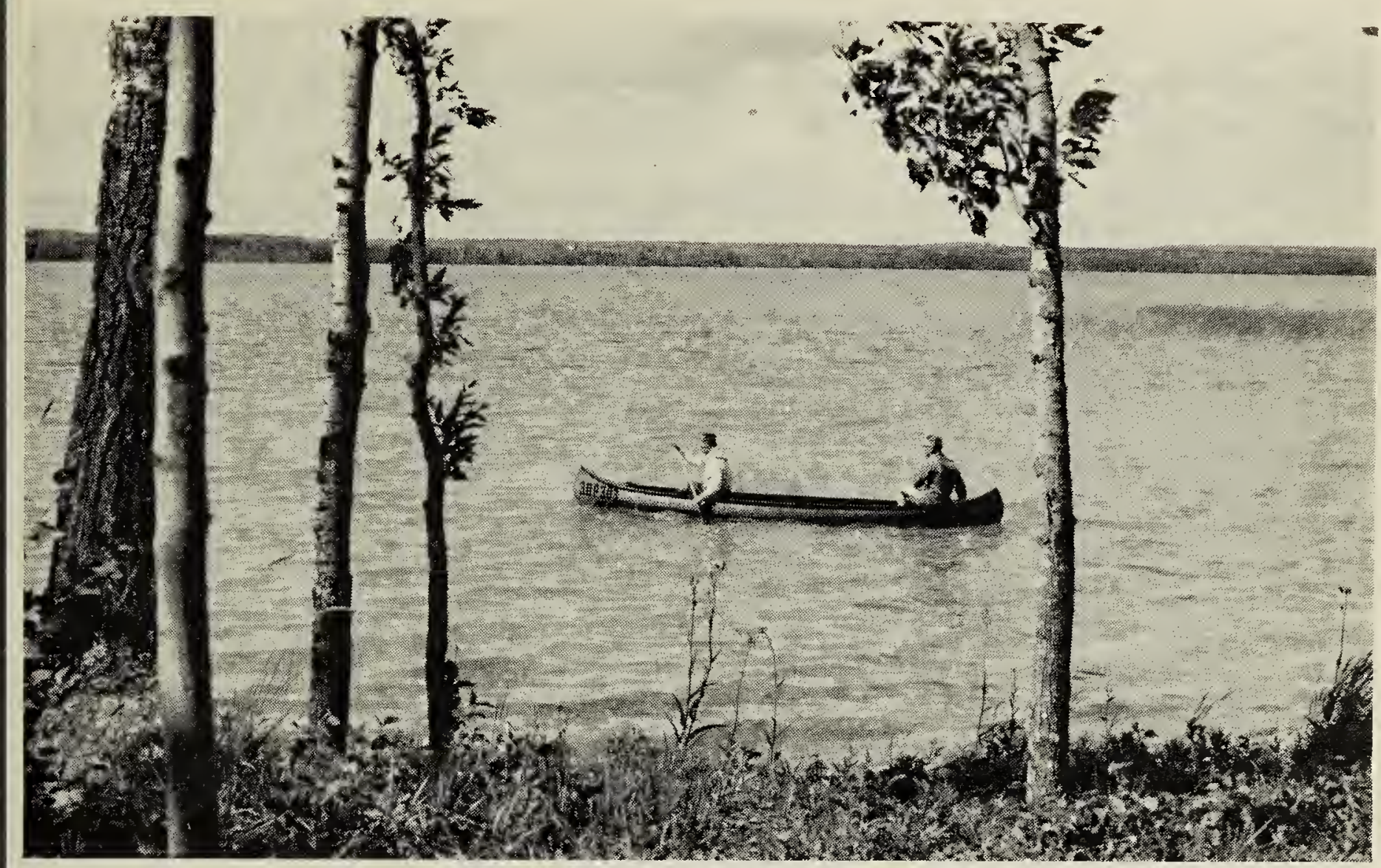

Natural landscape experience

Saskatchewan Government Photo

parks. Horses are destructive of natural vegetation and their manure along trails spoils the park atmosphere. Horseback riding is an activity that might well be relegated to the park boundaries and beyond. Bicycling is the logical alternative.

The horsepower of boats should be limited on all parks waters. A limit of 15 horsepower would keep the noise level down while also limiting the size, speed and wash of boats. Fast power boats should be banned from all lakes.

The parks policy is illogical as regards fishing. Hunting is not permitted but the killing of fish is. The argument is that fishing leaves the environment unimpaired, but this is an argument based on ignorance. It simply is not known to what extent other forms of life, for example predators such as mink and otter, are harned by man's competition with them for fish in streams and lakes. If the area is to be a wilderness, then fishing should be banned. As a minimum, the daily allowable catch should be severely restricted. The catching of fish in quantity to be taken out of the park for consumption elsewhere is reprehensible; it is a form of commercial fishing and is comparable to taking home firewood or Christmas trees from a National Park.

\subsection{Conclusion}

The plan for Prince Albert National Park is on the right track in its concern for preservation and for educating people in the "natural landscape experience". Attempts to make the Park serve the purposes of forms of recreation not consistent with the preservation-of-nature idea should be vigorously resisted, especially those forms involving commercial enterprises, power machinery and intensive activities drawing participants into crowds. The Park planners should be more daring and imaginative in developing a zoning system, land uses within zones and, in particular, the interpretive - educational aspects of Park programs. The National Parks have the opportunity to play an important role in developing an awareness of environment, and of the manland relationship, for the benefit of the Canadian people. This goal should be primary in the Prince Albert $\mathrm{Na}$ tional Park. 